\title{
抗血小板療法と抗凝固療法
}

\author{
宮下 史生 ${ }^{1)}$ ，豊田 一則 ${ }^{1)}$
}

1) 国立循環器病研究センター脳血管内科

\section{Antiplatelet and Anticoagulation Therapy}

\author{
Fumio Miyashita M.D. ${ }^{1)}$, Kazunori Toyoda M.D. ${ }^{1)}$ \\ 1) Department of Cerebrovascular Medicine, National Cerebral and Cardiovascular Center
}

Oral aspirin is highly recommended for acute antithrombotic therapy and secondary prevention in ischemic stroke patients. Clopidogrel and cilostazol presented as good or better effectiveness in reducing the risk of recurrent stroke than aspirin. Dual antiplatelet agents may be used with the exception of aspirin plus dipyridamole, which is not generally recommended for secondary stroke prevention because of the associated high bleeding risk. The addition of dabigatran to warfarin therapy was approved for ischemic stroke prevention in patients with non valvular atrial fibrillation (NVAF). In addition, novel oral anticoagulants (e. g., factor Xa inhibitors : rivaroxaban, apixaban) have been tested in several ongoing large randomized trials. When administering anticoagulant agents for patients with NVAF, the estimation of the embolic and bleeding risks using $\mathrm{CHADS}_{2}$ score, $\mathrm{CHA}_{2} \mathrm{DS}_{2}{ }^{-}$ VASc score and HASBLED score is recommended. In the Bleeding with Antithrombotic Therapy (BAT) Study group, the characteristics of bleeding complications in Japanese antithrombotic users were reported.

(Received December 27, 2011; accepted January 10, 2012)

Key words : antithrombotic therapy, antiplatelet therapy, anticoagulation therapy

Jpn J Neurosurg (Tokyo) $21: 779-790,2012$

\section{はじめに}

脳卒中診療において，抗血栓療法の効果と弊害を熟知 することは非常に重要である。脳梗塞の再発予防におい て，アスピリンやワルファリンなどの古典的な抗血栓薬 は多くのエビデンスを示し，近年ではより新しい抗血栓 薬も開発されてきている，各種学会が作成したガイドラ インにおいても，抗血栓療法は脳梗塞の再発予防におい て必要不可欠な治療法と位置づけられている. Table 1

と Table 2 に脳卒中ガイドライン 2009 における脳梗塞 の急性期および慢性期の抗血栓療法の指針を示す24). 一 方, 抗血栓療法は, 頭蓋内出血や消化管出血といった出 血性合併症の危険を常に孕んでいる。そのため，抗血栓
療法を行う際には，抗血栓療法による虚血性イベント抑 制効果と出血性イベントのリスク上昇を十分に考慮した うえで実施しなければならない。本稿では，脳梗塞診療 における抗血小板療法と抗凝固療法について概説し, さ らに抗血栓療法中の出血性合併症について述べたいと思 う.

\section{抗血小板療法}

抗血小板療法の虚血イベントの抑制効果はすでに証明 されている。本邦では，アスピリン，クロピドグレル， チクロピジン，シロスタゾールが内服で，才ザグレルナ トリウムが点滴で使用可能である。それぞれの薬剤の特

連絡先：宮下史生， 干211-0063 川崎市中原区小杉町 3-435 聖マリアンナ医科大学東横病院脳卒中センター脳卒中科 Address reprint requests to: Fumio Miyashita, M.D., Department of Strokology, Stroke Center, St. Marianna University Toyoko Hospital, 3-435 Kosugi-machi, Nakahara-ku, Kawasaki-shi, Kanagawa 211-0063, Japan 
Table 1 Guidelines for antithrombotic therapy in patients with acute ischemic stroke

\begin{tabular}{|c|c|c|}
\hline & 推 奨 & グレード \\
\hline $\begin{array}{l}\text { 抗血小板療法 } \\
1 \text {. }\end{array}$ & $\begin{array}{l}\text { オザグレルナトリウム } 160 \mathrm{mg} / \text { 日の点滴投与は，急性期（発症 } 5 \text { 日以内）の脳血栓症（心 } \\
\text { 原性脳塞栓症を除く）患者の治療法として推奨される. }\end{array}$ & B \\
\hline 2 . & $\begin{array}{l}\text { アスピリン 160〜300 mg/日の経口投与は，発症早期（48 時間以内）の脳梗塞患者の治療 } \\
\text { 法として推奨される. }\end{array}$ & A \\
\hline 抗凝固療法 & & \\
\hline 1 & $\begin{array}{l}\text { 発症 } 48 \text { 時間以内の脳梗塞ではへパリンを使用することを考慮してもよいが，十分な科学 } \\
\text { 的根拠はない. }\end{array}$ & $\mathrm{C} 1$ \\
\hline 2 . & $\begin{array}{l}\text { 脳梗塞急性期に低分子へパリン（保険適応外），ヘパリノイド（保険適応外）は使用する } \\
\text { ことを考慮してもよいが，十分な科学的根拠はない. }\end{array}$ & $\mathrm{C} 1$ \\
\hline 3 . & $\begin{array}{l}\text { 発症 } 48 \text { 時間以内で病変最大径が } 1.5 \mathrm{~cm} \text { を超すような脳梗塞（心原性脳塞栓症を除く）に } \\
\text { は, 選択的トロンビン阻害薬のアルガトロバンが推奨される. }\end{array}$ & B \\
\hline
\end{tabular}

グレード $\mathrm{A}$ ：行うよう強く勧められる。グレード $\mathrm{B}$ ：行うよう勧められる。グレード $\mathrm{C} 1$ ：行うことを考慮してもよい が，十分な科学的根拠がない. グレード C2：科学的根拠がないので，勧められない.

Table 2 Guidelines for antithrombotic therapy as secondary prevention for ischemic stroke

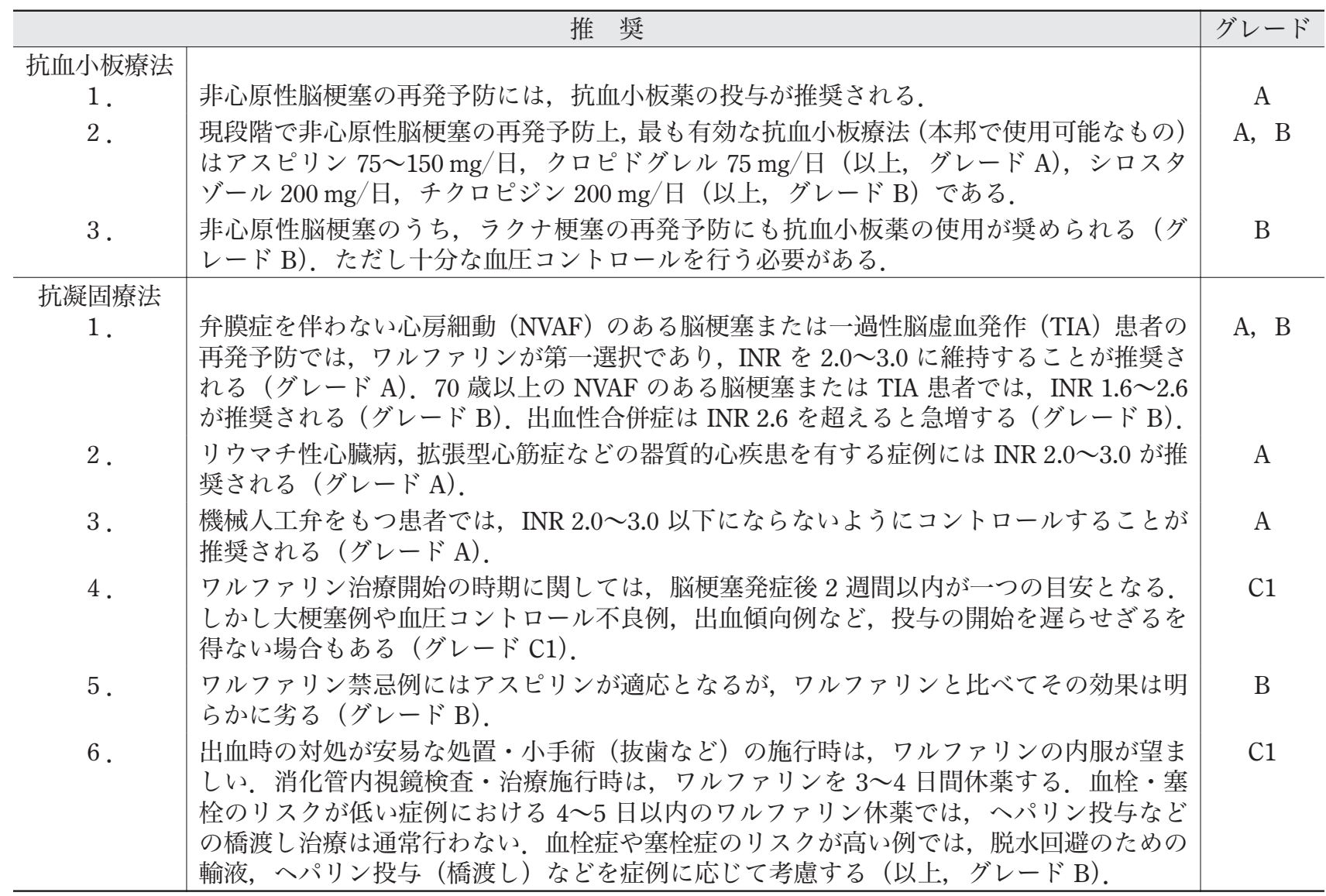

徵を踏まえて薬剤選択を行うことが重要である.

\section{1 アスピリン}

アスピリンはシクロオキシゲナーゼを不活化し，トロ ンボキサン $\mathrm{A}_{2}$ の合成を抑制する。 その結果，血小板凝集
が抑制され，抗血小板作用を発現する。アスピリンは， 全世界で最も広く使用されている抗血小板薬であり，急 性期から慢性期にかけて多くのエビデンスがある.

\section{1. 急性期治療}

本邦の脳卒中治療ガイドライン 2009 において，発症 
Table 3 Frequency of vascular events in patients with a history of stroke or transient ischemic attack in a meta-analysis by the Antithrombotic Trials' Collaboration (modified from ref. 1)

\begin{tabular}{lcccl}
\hline \multicolumn{1}{c}{ Outcome } & $\begin{array}{c}\text { Vascular events } \\
\text { antiplatelet }\end{array}$ & control & Benefit per 1,000 pts (SE) & p-value \\
\hline Non-fatal MI & 1.7 & 2.3 & $6(2)$ & 0.0009 \\
Non-fatal stroke recurrence & 8.3 & 10.8 & $25(5)$ & $<0.0001$ \\
Vascular death & 8.0 & 8.7 & $7(4)$ & 0.04 \\
Any death & 11.3 & 12.8 & $15(5)$ & 0.002 \\
MI, stroke or vascular death & 17.8 & 21.4 & $36(6)$ & $<0.0001$ \\
\hline
\end{tabular}

$\mathrm{MI}$ : myocardial infarction, $\mathrm{SE}:$ standard error of the mean

早期（48 時間以内）の脳梗塞患者の治療法としてアスピ リン 160〜300 mg/日の経口投与が推奨されている.また 米国や欧米でのガイドラインでもアスピリンの使用を強 く勧めている。これは, International Stroke Trial (IST) ${ }^{19)}$ と Chinese Acute Stroke Trial (CAST) $)^{4)}$ とう 2 つの大 規模試験によるところが大きい. IST では $300 \mathrm{mg} /$ 日， CAST は $160 \mathrm{mg} /$ 日のアスピリンをともに発症 48 時間 以内に開始し, IST では最大 4 週間, CAST では 2 週間, 治療を続けている。 この 2 つの大規模試験が対象の多く を占めている Cochrane review のメ夕解析では, 1,000 例 に抗血小板療法を行うごとに慢性期に自立できる患者 が 13 例増え, 完全に症状が回復する患者が 10 例増えて いた。 また症候性頭蓋内出血は 2 例増えるが, 脳梗塞再 発が 7 例, 肺塞栓が 1 例減る結果となった。一方, アス ピリン以外の経口抗血小板薬を急性期治療に用いること は，欧米のガイドラインでは推奨されていない.

\section{2. 慢性期再発予防}

本邦のガイドラインでは，非心原性脳梗塞の再発予防 においてアスピリン 75〜 $150 \mathrm{mg} /$ 日の投与が推奨されて いる. Antithrombotic Trialists' Collaboration (ATT) ${ }^{1)}$ は, 1997 年 9 月までに報告された 287 試験（総計 135,000 例）を対象に大規模なメ夕解析を実施し，血管疾患リス クが高い患者に対する抗血小板療法の効果を評価した。 その結果，抗血小板療法は，脳卒中または TIA の患者に おいて，対照治療に比べて非致死性の心筋梗塞，非致死 性の脳卒中再発，血管死および全死亡のリスクを有意に 低減させていた（Table 3)。 また，この検討のなかで， 脳卒中または TIA の患者において，アスピリンは対照治 療に比べて血管イベント（心筋梗塞，脳卒中，あるいは 致死性血管障害) の発生を $22 \%$ 低減させると報告されて いる，さらにアスピリンの血管イベント低減効果には $\mathrm{J}$ カーブ現象がみられ，75〜 $150 \mathrm{mg} /$ 日投与が最も大きな リスク低減効果 $(32 \%)$ があり，75 mg/日未満では有意 な効果がないと報告されている.

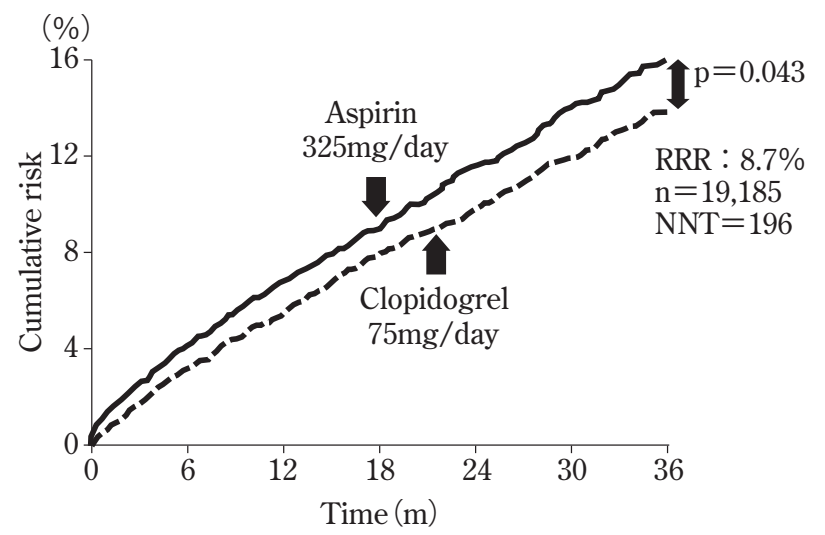

Fig. 1 Cumulative incidence of vascular disease (ischemic stroke, myocardial infarction, or vascular death) in CAPRIE (modified from ref. 3)

\section{2 クロピドグレル}

クロピドグレルは，血小板上のアデノシン二リン酸 (ADP) 受容体（P2Y12）を不可逆的に阻害することによ り, ADP 依存性の持続的な血小板凝集抑制効果を発揮す る。同じ作用機序であるチクロピジンに比べて，肝障害 や好中球減少などの副作用が少なく，1日 1 回投与であ るというメリットがある。本邦のガイドラインでは，非 心原性脳梗塞の再発予防にクロピドグレル $75 \mathrm{mg} /$ 日の 投与が推奨されている。クロピドグレルの有効性を示す 代表的なものは, Clopidogrel versus Aspirin in Patients at Risk of Ischemic Event (CAPRIE) 試験了)がある. CAPRIE 試験は，脳梗塞（発症 1 週間以上，6 力月以内)，心筋梗 塞，動脈硬化性末梢血管疾患を有する約 2 万例（脳梗塞 患者約 6,000 例）を対照としており，クロピドグレル単 独投与群（75 mg/日）が，アスピリン単独投与群（325 $\mathrm{mg} /$ 日）に比べて有意に全血管イベントを抑制していた と報告している（相対的リスク低下率 8.7\%；95\%CI $0.3 \sim 16.5 \%, p=0.043 ）$ (Fig. 1)。さらに CAPRIE 試験の 
Table 4 Incidences of primary and secondary endpoints in CSPS 2 (modified from ref. 27)

\begin{tabular}{|c|c|c|c|c|}
\hline & \multicolumn{2}{|c|}{ Patients $(\% /$ person-years $)$} & \multirow[t]{2}{*}{ Hazard ratio $(95 \% \mathrm{CI})$} & \multirow[t]{2}{*}{$\mathrm{p}^{-}$-value } \\
\hline & $\begin{array}{l}\text { Cilostazol } 200 \mathrm{mg} / \text { day } \\
\qquad(\mathrm{n}=1,337)\end{array}$ & $\begin{array}{l}\text { Aspirin } 81 \mathrm{mg} / \text { day } \\
(\mathrm{n}=1,335)\end{array}$ & & \\
\hline \multicolumn{5}{|l|}{ Primary endpoint } \\
\hline $\begin{array}{l}\text { Stroke (cerebral infarction, } \\
\text { cerebral hemorrhage, or subarach- } \\
\text { noid hemorrhage) }\end{array}$ & $82(2.76)$ & $119(3.71)$ & $0.743(0.564-0.981)$ & 0.0357 \\
\hline \multicolumn{5}{|l|}{ Secondary endpoints } \\
\hline Cerebral infarction & $72(2.43)$ & $88(2.75)$ & $0.880(0.645-1.200)$ & 0.4189 \\
\hline $\begin{array}{l}\text { Ischemic cerebrovascular disease } \\
\text { (cerebral infarction or transient } \\
\text { ischemic attack) }\end{array}$ & $86(2.90)$ & $103(3.21)$ & $0.898\left(0.675^{-1.194)}\right.$ & 0.4582 \\
\hline Death from any cause & $13(0.42)$ & $13(0.39)$ & $1.072(0.497-2.313)$ & 0.8600 \\
\hline Composite endpoints* & $138(4.66)$ & $186(5.81)$ & $0.799(0.643-0.994)$ & 0.0437 \\
\hline \multicolumn{5}{|l|}{ Safety endpoints } \\
\hline $\begin{array}{l}\text { Hemorrhagic events (cerebral } \\
\text { hemorrhage, subarachnoid hemor- } \\
\text { rhage or hemorrhage requiring } \\
\text { hospital admission) }\end{array}$ & $23(0.77)$ & $57(1.75)$ & $0.458(0.296-0.711)$ & 0.0004 \\
\hline
\end{tabular}

サブ解析では ${ }^{17)}$, 脂質代謝異常, 糖尿病合併, 冠動脈バ イパス手術の既往，虚血性疾患の既往，複数血管床の障 害を有するハイリスク症例において, 虚血性脳血管障害, 心筋梗塞，血管死，虚血性イベントや出血による再入院 の発生率は，いずれの危険因子群においてもクロピドグ レルはアスピリンよりも優れていた。クロピドグレルの 安全性に関しては, CAPRIE 試験においてアスピリンよ り消化管出血が有意に少なく（クロピドグレル $0.49 \%$ vs. アスピリン $0.71 \% ; \mathrm{p}=0.05)$, 発疹 (6.0\% vs. $4.6 \%$; $\mathrm{p}<0.001 ）$ と下痢（4.46\% vs. $3.36 \% ； \mathrm{p}<0.001 ）$ が有意 に多いと報告されている3 7). クロピドグレルの問題点と しては，肝代謝酵素である CYP2C19 の機能が低下して いる患者では, クロピドグレルの効果が減弱し，血管イ ベントのリスクが高まる可能性があることである。 CYP2C19 の遺伝子多型は, 日本人にも多いと報告されて おり，看過できないと思われる。

\section{3 シロスタゾール}

シロスタゾールは，本邦で開発された薬剤であり，血 小板や血管平滑筋に存在する PDE3 (phosphodiesterase type 3）を選択的に阻害することで抗血小板作用と血管 拡張作用を発揮する。本邦のガイドラインでは，非心原 性脳梗塞の再発予防にシロスタゾール $200 \mathrm{mg} /$ 日が推奨 されている. シロスタゾールの有効性を示す代表的なも のは, Cilostazol Stroke Prevention Study (CSPS) ${ }^{14)}$ があ
る。 CSPS は日本人の脳梗塞症例を対象としたプラセボ 対照無作為化二重盲検試験であり，シロスタゾールはプ ラセボに比較し，41.7\%の有意な脳梗塞再発予防効果が 示されている。シロスタゾールとアスピリンの比較試験 は, 中国から Cilostazol versus Aspirin for Secondary Ischemic Stroke Prevention (CASISP) 試験 ${ }^{18)}$ が報告され ている。同試験では，シロスタゾール（200 mg/日）の 内服の脳卒中再発低減効果はアスピリン $(100 \mathrm{mg} /$ 日) と同等であり，脳出血合併率はアスピリンより有意に少 なかった。 日本で行われたシロスタゾールとアスピリン との比較試験 CSPS II $\left.{ }^{27}\right)$ では，シロスタゾール $(200 \mathrm{mg}$ 日）は，アスピリン（81 mg/日）より，脳卒中の再発を 有意に低減し (Relative Risk Reduction：RRR 25.7\%, p= 0.0357 ), 出血性イベント（脳出血, くも膜下出血, 入院 を要する出血）も少ない（RRR 54.2\%, p=0.0004）こと が示された (Table 4)。サブ解析では ${ }^{30)}$, 特にラクナ梗塞 症例において脳出血合併率がシロスタゾールで有意に低 いという結果が示された。シロスタゾールの問題点とし ては，頭痛と頻脈が挙げられるが，頭痛に関しては少量 からの漸増投与である程度コントロール可能である.

\section{4 抗血小板薬の併用療法}

抗血小板薬はそれぞれ作用機序が異なるため，複数の 抗血小板薬を併用すると脳梗塞の再発予防低減効果が高 まることが予想される。欧米では，アスピリンとホスホ 
ジエセテラーゼ阻害薬であるジビリダモールとの合剤 が，ガイドラインで第 1 選択として勧められている。こ の合剤の脳梗塞患者への虚血イベント再発予防効果に関 して, European Stroke Prevention Study $(\text { ESPS2) })^{8)}$ European Australasian Stroke Prevention in Reversible Ischemic Trial (ESPRIT) ${ }^{11)}$ の 2 つ試験でアスピリンへ の優越性が示されている。 またクロピドグレルへの非劣 性が Prevention Regimen for Effectively avoiding Second Strokes (PRoFESS) ${ }^{26)}$ で示されている. 同じホスホジエス テラーゼ阻害薬であるシロスタゾールとアスピリンの併 用については, シロスタゾール $(200 \mathrm{mg} /$ 日) とアスピ リン（100 mg/日）の併用療法が, 頭蓋内動脈狭窄によ る脳梗塞症例の狭窄病変進展の抑制に有効であること が, 韓国の多施設共同試験 Trial of cilOstazol in Symptomatic intracranial arterial Stenosis(TOSS) ${ }^{21)}$ で示されてい る.

アスピリンとクロピドグレルの併用療法については, 頚動脈ステント留置術の前後などの限られた状況以外に 勧められてはいない.これは, 脳梗塞症例にクロピドグ レル単剤服用とアスピリンとの併用を比べた Management of ATherothrombosis with Clopidogrel in High-risk patients with recent transient ischemic stroke study $(\mathrm{MATCH})^{9)}$ や, 脳梗塞を含む血管病症例および一部無症 候性の患者にアスピリン単剂服用とクロピドグレルとの 併用を比べた Clopidogrel for High Atherothrombotic Risk and Ischemic Stabilization Management and Avoidance study (CHARISMA) ${ }^{2)}$ で, 併用による虚血イベント 発症の軽減が有意でなく, 出血イベントが増える傾向に あったことによる。一方, 頝動脈プラークからの微小栓 子シグナル (Microembolic signals：MES) が同定できる脳 梗塞症例を対象とした Clopidogrel and Aspirin for Reduction of Emboli in Symptomatic Carotid Stenosis (CARESS) 試験 ${ }^{22)}$ 頭蓋内に症候性狭窄性病変をもち MES を同定 できる脳梗塞症または TIA 症例を対象とした Clopidogrel plus Aspirin versus Aspirin alone for reducing embolisation in patients with acute symptomatic cerebral or carotid artery stenosis (CLAIR) 研究31)のいずれも, 発症 早期のアスピリンとクロピドグレルの併用がアスピリン 単独と比べ脳梗塞発症との関連が高い MES の検出を有 意に抑制したと報告している。また少数例の検討ではあ るが, Fast Assessment of Stroke and Transient ischemic attack prevent Early Recurrence（FASTER）研究20)では, TIA や軽症脳梗塞症例を対象に, 発症 90 日後までのア スピリンとクロピドグレルの併用療法がアスピリン単独 よりも再発予防効果が出血合併症に勝る可能性を報告し
ている。これらを勘案すると，クロピドグレルとアスピ リンの併用が考慮される状況としては, 澒動脈や頭蓋内 に症候性狭窄病変の存在する症例において, 発症 3 力月 以内の短期間のみであると考えられる.

\section{抗凝固療法}

脳梗塞に対して急性期に抗凝固療法を行うことは，力゙ イドラインで推奨されている発症 48 時間以内の 15 $\mathrm{mm}$ を超える非心原性脳梗塞に対するアルガトロバン投 与以外には，有効性が証明されたものはない。抗凝固療 法は，主に急性期以降の心原性脳塞栓症の再発予防目的 に使用されることが多い. 現在, 抗凝固療法としてワル ファリン, ダビガトランが経口投与，ヘパリン，アルガ トロバンが点滴投与で使用可能である。抗凝固療法は, 凝固因子 Xa 因子阻害薬が経口薬として新規開発中であ り, 近い将来使用可能となり, 抗凝固療法の治療方針が 大きく変わる可能性がある.

\section{1 ワルファリン}

ワルファリンは, ビタミン $\mathrm{K}$ 依存性の凝固因子の合成 を抑制することにより，トロンビンの生成を抑制する間 接的トロンビン阻害薬である。非弁膜症性心房細動 (NVAF) の脳卒中予防を目的として行われたメタアナリ シスでは ${ }^{16)}$, 用量調節法によるワルファリン投与は，プ ラセボに対して $64 \%$ というきわめて高い脳卒中予防効 果があり, ワルファリンは最も強力なエビデンスをもつ 薬剤として世界的にコンセンサスが確立している。一方, ワルファリンがもつ出血リスクについては十分な配慮が 必要であり, 虚血性脳卒中と出血性脳出血を合わせた全 脳卒中発症を最小限にするワルファリンの強度として INR 2.0 3.0 の範囲が全世界的にも推奨されている. 日 本では, 70 歳以上の高齢者では重篤な出血性合併症の危 険性が大きくなることを勘案して，INR1.6〜2.6 を推奨 している. また近年, 心房細動症例の塞栓症や出血のリ スクを評価し，より適切な抗凝固療法を行うためのスコ アリングが使用されている.

\section{1. 心房細動患者の塞栓症リスク $\mathrm{CHADS}_{2}$ スコア ${ }^{13)}$}

心房細動患者における脳梗塞発症率を簡便に評価する 基準である. $\mathrm{CHADS}_{2}$ とは，うっ血性心不全 (Congestive heart failure), 高血圧 (Hypertension), 75 歳以上 (Age $\geqq 75 \mathrm{y}$ ），糖尿病（Diabetes），脳卒中または TIA の既往 （prior S Stroke/TIA）の頭文字で，脳梗塞または TIA の既 往には 2 点, 残りの各項目には 1 点を与えた合計 6 点満 


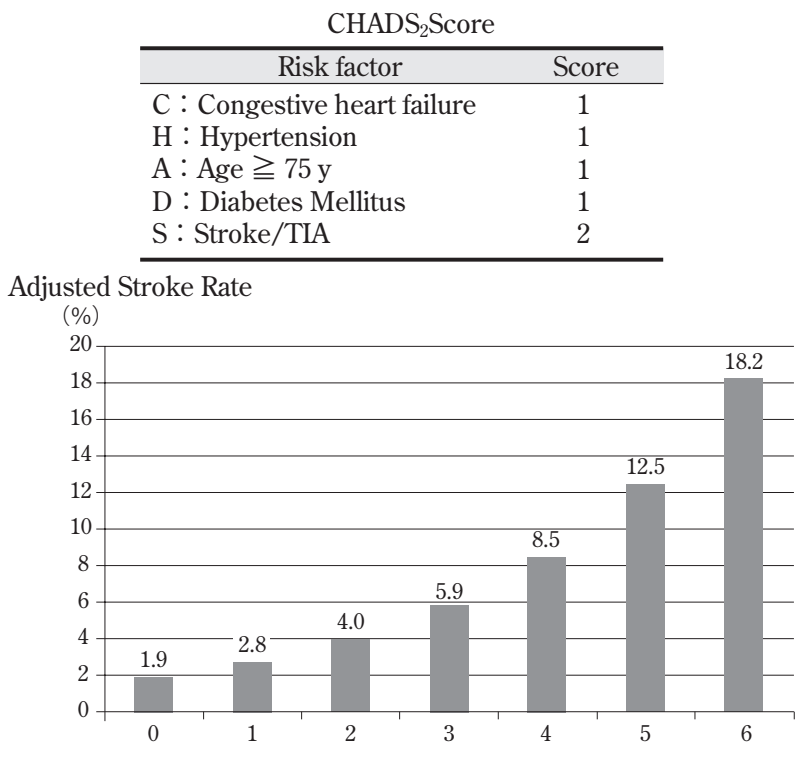

Fig. 2 Adjusted stroke rate according to $\mathrm{CHADS}_{2}$ Score (modified from ref. 13)

点のスコアである。この点数が増加するにつれて年間の 脳梗塞発症リスクは高まり, 過去の報告では脳梗塞の年 間発症率は 0 点 $1.9 \%, 1$ 点 $2.8 \%, 2$ 点 $4.0 \%, 3$ 点 $5.9 \%$, 4 点 $8.5 \%, 5$ 点 $12.5 \%, 6$ 点 $18.2 \%$ とされている (Fig. 2). 本邦の心房細動治療ガイドライン ${ }^{23)}$ では, $\mathrm{CHADS}_{2}$ が 2 点以上でワルファリン療法を推奨し, 1 点で考慮しても 可とされている.

\section{$\mathrm{CHA}_{2} \mathrm{DS}_{2}-\mathrm{VASc}$ スコア}

$\mathrm{CHADS}_{2}$ スコアは簡便なりスク評価法ではあったが, スコアが 0 1 の低リスク患者の抗血栓療法をどうする かという問題があった. 2010 年に改訂された ESC (European Society of Cardiology) の心房細動のガイドライン12) では $\mathrm{CHADS}_{2}$ スコアをさらに細分化した $\mathrm{CHA}_{2} \mathrm{DS}_{2}{ }^{-}$ VASc スコアが導入されている.このスコアは 75 歳以上 $\left(\mathrm{A}_{2}\right)$ および過去の塞栓症の既往 $\left(\mathrm{S}_{2}\right)$ を 2 点とし, うつ 血性心不全 (C), 高血圧 (H), 糖尿病 (D), 動脈硬化 性疾患 (V), 65〜74 歳 (A), 女性（Sc）をそれぞれ 1 点とするものである. $\mathrm{CHA}_{2} \mathrm{DS}_{2}-\mathrm{VASc}$ スコアが 0 点の心 房細動患者では脳卒中の年間発症率は $0 \%$ であり（Fig. 3), 2 点以上の場合に抗凝固療法, 1 点の場合は抗凝固 療法もしくはアスピリン 75〜 $325 \mathrm{mg}$ /日が推奨されてい る. 0 点の場合はアスピリンもしくは無治療で, むしろ 無治療が望ましいとされている。つまり, 65 歳未満の男 性の NVAF 患者以外は, すべて抗凝固療法の適応を積極 的に考慮する指針となっている (Fig. 4).
$\mathrm{CHA}_{2} \mathrm{DS}_{2}-$ Vasc Score

\begin{tabular}{lc}
\hline \multicolumn{1}{c}{ Risk factor } & Score \\
\hline $\mathrm{C}:$ Congestive heart failure & 1 \\
$\mathrm{H}:$ Hypertension & 1 \\
$\mathrm{~A}:$ Age $\geqq 75 \mathrm{y}$ & 2 \\
$\mathrm{D}:$ Diabetes Mellitus & 1 \\
$\mathrm{~S}:$ Stroke/TIA/thrombo-embolism & 2 \\
$\mathrm{~V}:$ Vascular disease* & 1 \\
$\mathrm{~A}:$ Age 65-74 y & 1 \\
Sc $:$ Sex category (female sex) & 1 \\
\hline * prior myocardial infarction, peripheral & \\
artery disease, aortic plaque &
\end{tabular}

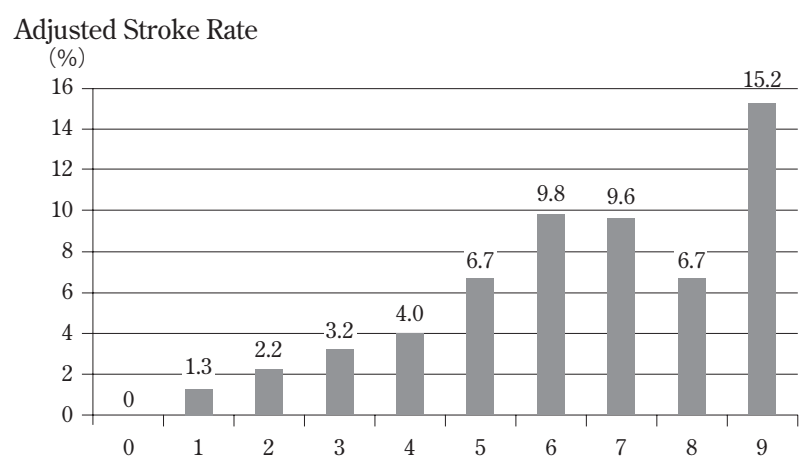

Fig. 3 Adjusted stroke rate according to $\mathrm{CHA}_{2} \mathrm{DS}_{2}$-Vasc Score (modified from ref. 12)

\section{2. 心房細動患者の出血リスク}

\section{HAS-BLED スコア}

心房細動患者に抗凝固療法を行う場合の大出血のリス クを評価する方法として，2010 年の ESC ガイドライ ン12)にて HAS-BLED スコアが提唱された。 HAS-BLED とは, 高血圧 (収縮期血圧 $>160 \mathrm{mmHg}$, Hypertension), 腎・肝機能異常 (各 1 点, Abnormal renal and liver function), 脳卒中 (Stroke), 出血の既往 (Bleeding), INR が不安定または高值（Labile INRs），高齢者（65 歳 以上, Elderly), 薬剤とアルコール (各 1 点, Drugs and alcohol）の頭文字で，最大 9 点のスコアとなる. 3 点以 上は高リスク患者として, 抗凝固療法や抗血小板療法の 導入に際して厳格な注意を喚起している。なお本スコア は先ほど述べた $\mathrm{CHADS}_{2}$ スコアや $\mathrm{CHA}_{2} \mathrm{DS}_{2}-\mathrm{VASc}$ スコ アとオーバーラップしている項目がある。つまり, $\mathrm{CHADS}_{2}$ スコアや $\mathrm{CHA}_{2} \mathrm{DS}_{2}-\mathrm{VASc}$ スコアが高く塞栓症 のリスクが高い症例では，同時に出血性リスクが高いこ とを示している。これらの患者に抗凝固療法を行う際に は, 本スコアで介入可能な高血圧のコントロール, 安定 した INR でのワルファリン処方，節酒などに努める. 


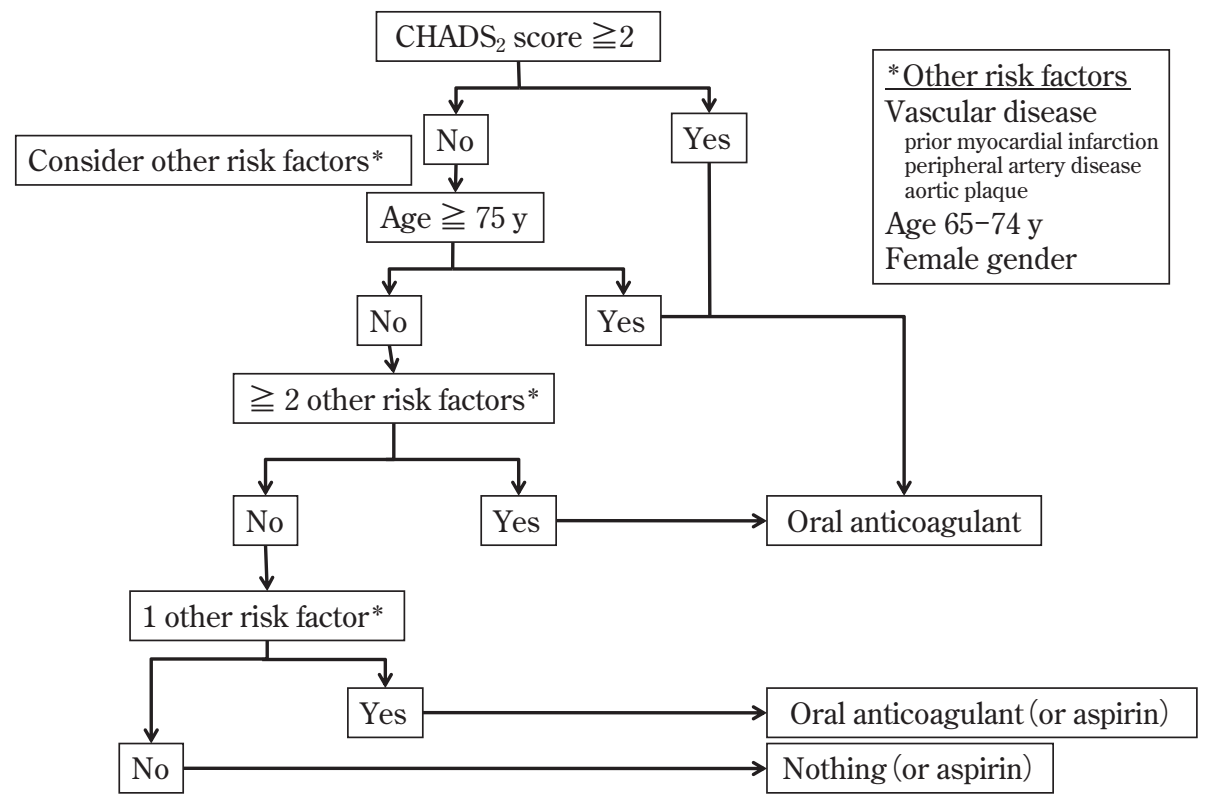

Fig. 4 Clinical flowchart for the use of oral anticoagulation for stroke prevention in AF; ESC Guideline for the management of $\mathrm{AF}$ (modified from ref. 12)

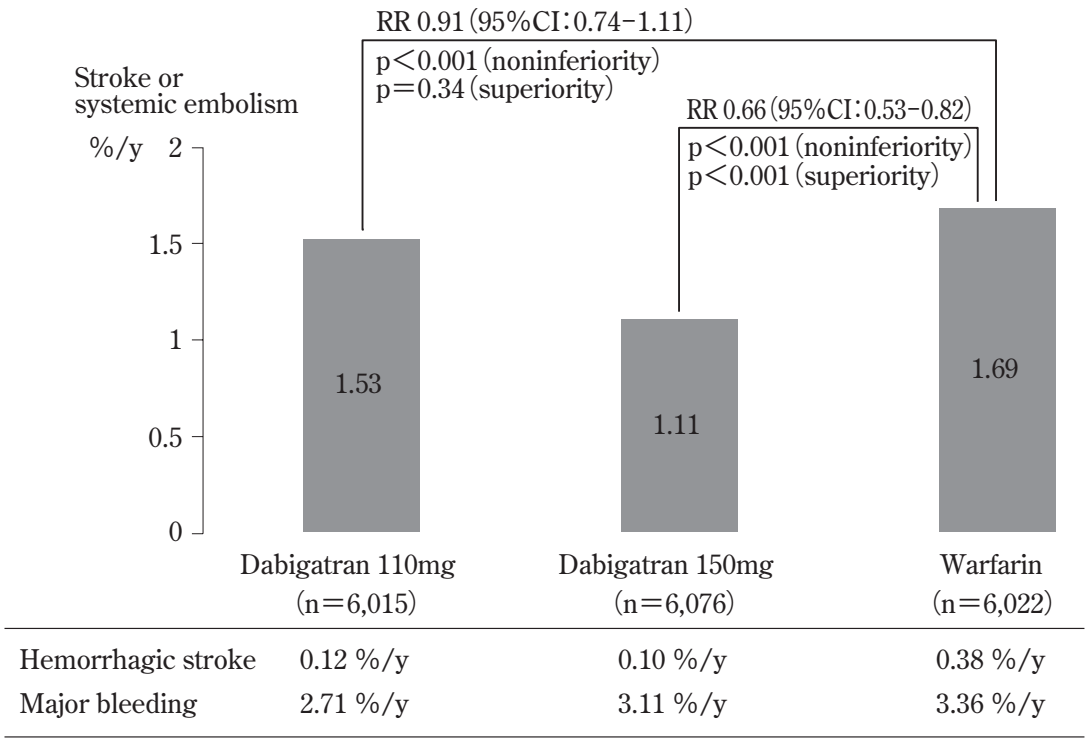

Fig. 5 Efficacy and safety outcome of dabigatran compared with warfarin in the RE-LY trial (modified from ref. 5)

\section{2 ダビガトラン}

ダビガトランはトロンビンを特異的に阻害する経口抗 凝固薬であり, 2011 年 1 月に本邦でもダビガトラン 110 $\mathrm{mg} \times 2 /$ 日と $150 \mathrm{mg} \times 2 /$ 日の 2 用量が認可された。ダビ ガトランの代謝にはチトクローム P450 が関与せず，チ トクローム P450 酵素活性を誘導せず，抑制することも
ないので，抗凝固活性が遺伝子の制御を受けることがな く,抗凝固療法の個人差がきわめて少ないと考元れる. ダビガトランの大規模臨床試験としては, 2009 年に発表 された Randomized Evaluation of Long Term Anticoagulant Therapy（RELY）試験5)がある，RELY 試験では，高 リスク（脳卒中，TIA または全身性塞栓症の既往，左室 
機能不全, 75 歳以上, 高血圧・冠動脈疾患・糖尿病のい ずれかを有する 65 歳以上) の NVAF 18,113 例を対象に, ダビガトラン $220 \mathrm{mg} /$ 日, $300 \mathrm{mg} /$ 日, ワルファリン (目 標 INR 2.0 3.0) が盲検下で投与され, 少なくとも 1 年, 中央值で 2 年間追跡調査が行われた。一次評価項目であ る「出血性を含む脳卒中または全身性塞栓症」は，ワル ファリン $(1.69 \% /$ 年 $)$ より, ダビガトラン $300 \mathrm{mg} /$ 日 $(1.11 \% /$ 年) で有意に少なく, ダビガトラン $220 \mathrm{mg} /$ 日 (1.53\%/年) でも非劣性が証明された。また出血性脳卒 中は, いずれのダビガトラン投与群 $(220 \mathrm{mg} /$ 日 ; 0.12\%/ 年, $300 \mathrm{mg} /$ 日 $; 0.10 \% /$ 年）においてもワルファリン投 与群 $(0.38 \% /$ 年 $)$ より有意に少なく, 大出血もダビガト ラン $220 \mathrm{mg} /$ 日 (2.71\%/年) ではワルファリン $(3.36 \% /$ 年）より有意に少なくなっていた（Fig. 5)。また RELY 試験のサブ解析 ${ }^{10)}$ では, 脳卒中または TIA の既往を有す る NVAF 患者において, いずれのダビガトラン投与群 $(220 \mathrm{mg} /$ 日； $0.25 \% /$ 年， $300 \mathrm{mg} /$ 日；0.53\%/年）でもワ ルファリン $(1.28 \% /$ 年 $)$ より出血性脳卒中の発症率が有 意に低くなっていた。このようにダビガトランは, NVAF を有する脳卒中患者の再発予防においてワルファリンと 同等以上の有効性と安全性をもっており, ビ夕ミン K 非 依存性であることから, 食事や薬物の相互作用（イトラ コナゾール, ベラパミル, アミオダロン, カルバマセピ ンは要注意）も比較的少なく, 用量調節も不要で簡便で あることから, 今後の抗凝固療法を大きく変化させる可 能性がある。 また, ダビガトランは直接凝固系カスケー ドに作用するため, 服用後効果発現・消失ともに比較的 早く, ワルファリンに比べて脳梗塞急性期の導入をス ムーズに行うことができ, 観血的手術・処置時の休薬に 関してもワルファリンょり煩雑さは減ると思われる。一 方, 服薬コンプライアンスが不良であれば， 1 回の休薬 で効果が消失する可能性があることや出血時の効果的な 中和治療法が確立されていないという問題点もある. 特 に禁忌とされている透析患者や腎不全患者に使用して頭 蓋外出血を発症し死亡した例が報告され，厚生労働省も 警告文書を発令して注意を促している。ダビガトランは ワルファリンより出血性脳卒中のリスクは少ないが, 頭 蓋外出血のリスクは同等であり, 腎機能低下例や高齢者 では用量を含めて慎重な対応が必要である。また，現在 ダビガトラン投与中に脳梗塞を発症した場合, ワルファ リンのような $\mathrm{rt}$-PA 静注療法に関する明確な指針は存 在しておらず，今後検討が必要になると思われる。

\section{Rivaroxaban}

Rivaroxaban は凝固 Xa 因子の阻害薬として開発され
た経口投与可能な抗凝固薬であり, トロンビン産生を抑 制することで抗血栓作用を発揮する，NVAF 患者におけ る脳卒中, 全身性塞栓症の発症抑制に関して, rivaroxaban のワルファリンに対する非劣性を検証するために, 国際共同第 III相試験として Rivaroxaban once daily Oral direct factor Xa inhibition Compared with Vitamin $\mathrm{K}$ antagonist for the prevention of stroke and Embolism Trial in Atrial Fibrillation (ROCKET AF) 試験 ${ }^{25)}$ と日本人 を対象とした J-ROCKET AF 試験の 2 つが施行されて いる. ROCKET AF 試験では, $\mathrm{CHADS}_{2}$ スコアが 2 以上 の NVAF 患者を対象とし, rivaroxaban 群 $(20 \mathrm{mg} /$ 日, た だし CCr 30〜 $49 \mathrm{ml} / \mathrm{min}$ の腎機能障害患者では $15 \mathrm{mg} /$ 日） 7,081 例とワルファリン群（目標 INR $2.5: 2.0 〜 3.0$ ) 7,090 例に割り付けられた。脳卒中と全身性塞栓症によ る一次エンドポイント発生リスクは, rivaroxaban 群 $1.71 \%$ 年, ワルファリン群 $2.16 \%$ で非劣性であることが 示された. 脳出血や致死性出血は, rivaroxaban 群で有意 に少なかったが（脳出血; rivaroxaban 群 $0.5 \%$ vs. ワル ファリン群 $0.7 \%, \mathrm{p}=0.02$, 致死性出血; $0.2 \%$ vs. $0.5 \%$, $\mathrm{p}=0.003)$, 大出血や臨床的に処置を要した出血は両群間 で差がなかった（rivaroxaban 群 14.91\%，ワルファリン 群 $14.52 \%)$ ．RELY 試験では，対象の $\mathrm{CHADS}_{2}$ スコアは 2.1 であったのに対して, 本試験の $\mathrm{CHADS}_{2}$ スコアは 3.5 と脳卒中高リスク患者を対象としているため, ダビガト ランとの単純な効果の比較は困難であるが, 高リスク患 者に対する新規抗血栓薬として rivaroxaban の有効性を 示す貴重な報告といえる. J-ROCKET AF 試験は, rivaroxaban の日本人におけるワルファリンに対する安全性 の非劣性を検証するために行われた。基本的な対象の組 み入れ基準や評価項目は ROCKET AF と同一であった が，投与量を rivaroxaban 群では $15 \mathrm{mg} /$ 日（CCr 30〜 49 $\mathrm{ml} / \mathrm{min}$ では $10 \mathrm{mg} /$ 日), ワルファリン群の目標 INR を 70 歳以上では $1.6 \sim 2.6,70$ 歳未満では $2.0 \sim 3.0$ として いた. 2011 年 7 月の第 23 回国際血栓止血学会で結果が 報告され, 日本独自の用量における rivaroxaban の安全性 が確認されている。

\section{Apixaban}

Apixaban も rivaroxaban と同様に経口投与可能な凝固 Xa 因子阻害薬として開発されているが, rivaroxaban が 1 日 1 回投与に対して本薬剤は 1 日 2 回投与である. Apixaban は,ワルファリンなどのビタミン K 拮抗薬に対 する忍容性がない NVAF 患者 5,999 例を対象に, 脳卒中 または全身性塞栓症の発症予防効果をアスピリンと比較 した apixaban versus acetylsalicylic acid to prevent stroke 


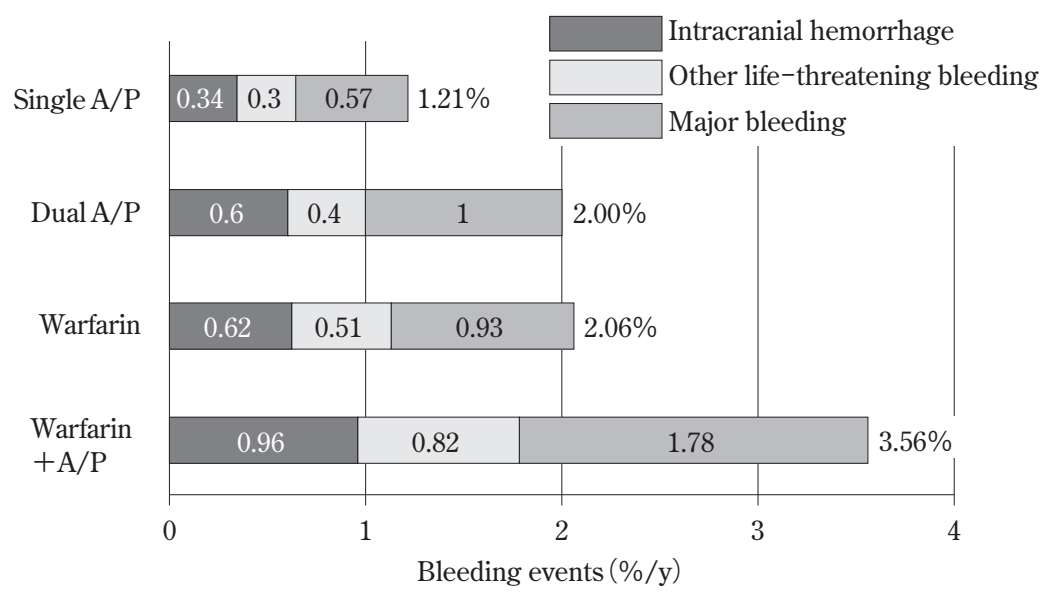

Bleeding events were classified according to the MATCH trial definition ${ }^{9)}$. Main antiplatelet agent in the single antiplatelet (A/P) group was aspirin (71\%), in the dual $\mathrm{A} / \mathrm{P}$ group it was aspirin plus ticlopidine (63\%), and in the $\mathrm{W}+\mathrm{A} / \mathrm{P}$ group it was aspirin $(71 \%)$.

Fig. 6 Incidence of life-threatening or severe bleeding events in Japanese antithrombotic users: the BAT study (modified from ref. 28)

in arterial fibrillation patients who have failed or are unsuitable for vitamin $\mathrm{K}$ antagonist treatment (AVERROES）試験 ${ }^{6)}$ とビタミン K 適格と判断された NVAF 患 者 18,201 例を対象にワルファリンに対する apixaban の 非劣性を検討した Apixaban for Reduction In STroke and other ThromboemboLic Events in arterial fibrillation (ARISTOTLE) 試験 ${ }^{15)}$ がある. AVERROES 試験では, apixaban 群 (10 mg/日) は, アスピリン群 (81〜 324 mg/ 日）に比較して, 脳卒中または全身性塞栓症の発症が有 意に減少した（apixaban 群 1.6\%/年，アスピリン群 $3.7 \%$ /年).一方, 大出血の発生は apixaban 群 $1.4 \%$ /年, アスピリン群 $1.2 \%$ /年で両群間に有意差はなかった。 ARISTOTLE 試験では, apixaban 群 $(10 \mathrm{mg} /$ 日) は, ワ ルファリン群（目標 INR 2.0 3.0）と比較して, 脳卒中 および全身性塞栓症の発症の予防効果において非劣性か つ優越性が証明された (apixaban 群 1.27\%/年, ワルファ リン群 $1.60 \%$ /年).また大出血（apixaban 群 $2.13 \%$ / 年, ワルファリン群 $3.09 \%$ /年) や出血性脳卒中 (apixaban 群 $0.24 \%$ 年, ワルファリン群 $0.47 \%$ /年) に関しても, apixaban がワルファリンより優れているという結果であり, 先行するダビガトランや rivaroxaban と同様な効果と安 全性が示された。

\section{抗血栓療法中の出血合併症}

抗血栓療法を施行する際には常に出血性合併症に留意 しなければならない。ワルファリンは用量依存的に出血
性イベントのリスクを高めることが知られており，抗血 小板薬も出血性イベントのリスクを上昇させる傾向があ る. 複数の抗血栓薬を使用すると, 一般に出血性合併症 は増加する．特に日本人を含むアジア系人種であること は，頭蓋内出血の危険因子である可能性が指摘されてお り，抗血栓療法を施行する際には注意が必要である。国 内で行われた多施設共同観察研究である Bleeding with Antithrombotic Therapy（BAT）研究28)では，脳血管障害 や心臓血管病に対して抗血栓薬を投与されている患者 4,009 例を前向きに登録し, 中央值で 19 力月間の観察を 行った。 その結果，抗血小板薬単剤服用患者の重篤ない し重症出血イベント発症率は $1.21 \%$ 年（うち頭蓋内出 血は $0.33 \% /$ 年) で, これに比べて抗血小板薬 2 剂服用 患者やワルファリン服用患者では 2 倍近く, ワルファリ ン・抗血小板薬服用患者では 3 倍の出血が発症してい た（Fig. 6).また BAT 研究において頭蓋内出血を起こし た群と頭蓋内出血以外の重篤または重症出血を起こした 群, 重篤または重症出血を起こさなかった群の 3 群で外 来での血圧の推移を比較した付随研究29)では, 登録時に は 3 群間の血圧レベルに差はなかったが，その後の観察 で頭蓋内出血群のみ血圧が漸増しているという結果で あった．抗血栓療法中の血圧管理の重要性を示している と思われる。

\section{1. 抗凝固療法中の出血合併症に対する対策}

ヘパリン投与中の出血性合併症には，程度に応じてへ パリンの減量や中止，および硫酸プロタミンによる中和 で対応する。ワルファリン服用中の出血性合併症には, 
ワルファリンを減量または中止し, 必要に応じてビ夕ミ ン K を投与する.さらに頭蓋内出血のような重篤な出血 のため, 早急にワルファリンの効果を是正する必要があ る場合には，乾燥七ト血液凝固第IX因子複合体の有効性 が報告されている ${ }^{32)}$. ビタミン $\mathrm{K}$ 単独投与では十分な是 正に 6 時間程度を要するのに対し, 乾燥七ト血液凝固第 IX因子複合体は投与 10 分程度で INR を十分に下げるこ とが可能である。しかし, 乾燥ヒト血液凝固第IX因子複 合体の単独投与のみでは, 12〜24 時間後には効果が減弱 することから, ビ夕ミン K を併用し効果を持続させるこ とが推奨されている。

\section{2. 抗血小板療法中の出血合併症に対する対策}

抗血小板薬服用患者に出血性合併症が起こった場合, 軽症を除き抗血小板薬を減量もしくは中止するのが望ま しい. 多くの抗血小板薬の効果が不可逆的であるため, 効果を早急に是正するには，血小板輸血を行うしかない が，血小板輸血は一般的な治療法とは言い難い.

\section{おわりに}

高齢化社会が進むにつれ，今後さらに重要となる抗血 栓療法について概説した。新規薬剤の登場により，抗血 栓療法の治療方針は混沌となることが予想されるが, 個々の患者ごとに，効果とリスクを十分に評価し，適切 な抗血栓療法を選択していくことが望まれる.

\section{文 献}

1) Antithrombotic Trialists' Collaboration: Collaborative meta-analysis of randomized trials of antiplatelet therapy for prevention of death, myocardial infarction, and stroke in high risk patients. BMJ 324: 71-86, 2002.

2) Bhatt DL, Fox KA, Hacke W, Berger PB, Black HR, Boden WE, Cacoub P, Cohen EA, Creager MA, Easton JD, Flather MD, Haffner SM, Hamm CW, Hankey GJ, Johnston SC, Mak KH, Mas JL, Montalescot G, Pearson TA, Steg PG, Steinhubl SR, Weber MA, Brennan DM, FabryRibaudo L, Booth J, Topol EJ ; CHARISMA Investigators : Clopidogrel and aspirin versus aspirin alone for the prevention of atherothrombotic events. $N$ Engl J Med 354: 1706-1717, 2006.

3) CAPRIE Steering Committee: A randomized, blinded, trial of clopidogrel versus aspirin in patients at risk of ischaemic events (CAPRIE). Lancet 348:1329-139, 1996.

4) CAST (Chinese Acute Stroke Trial) Collaborative Group : CAST : Randomised placebo-controlled trial of early aspirin use in 20000 patients with acute ischaemic stroke. Lancet 349: 1641-1649, 1997.

5) Connolly SJ, Ezekowitz MD, Yusuf S, Eikelboom J, Oldgren J, Parekh A, Pogue J, Reilly PA, Themeles E, Varrone J, Wang S, Alings M, Xavier D, Zhu J, Diaz R, Lewis
BS, Darius H, Diener HC, Joyner CD, Wallentin L; RELY Steering Committee and Investigators: Dabigatran versus warfarin in patients with atrial fibrillation. $N$ Engl $J$ Med 360: 2066-2078, 2009 .

6) Connolly SJ, Eikelboom J, Joyner C, Diener HC, Hart R, Golitsyn S, Flaker G, Avezum A, Hohnloser SH, Diaz R, Talajic M, Zhu J, Pais P, Budaj A, Parkhomenko A, Jansky P, Commerford P, Tan RS, Sim KH, Lewis BS, Van Mieghem W, Lip GY, Kim JH, Lanas-Zanetti F, Gonzalez-Hermosillo A, Dans AL, Munawar M, O'Donnell M, Lawrence J, Lewis G, Afzal R, Yusuf S; AVERROES Steering Committee and Investigators: Apixaban in patients with atrial fibrillation. N Engl J Med 364: 806-817, 2011.

7) Creager MA: Results of the CAPRIE trial: efficacy and safety of clopidogrel. Clopidogrel versus aspirin in patients at risk of ischaemic events. Vasc Med 3:257260, 1998.

8) Diener HC, CunhaL, Forbes C, Sivenius J, Smets P, Lowenthal A: European stroke prevention study 2: Dipyridamole and acetylsalicylic acid in the secondary prevention of stroke. J Neurol Sci 143: 1-13, 1996.

9) Diener HC, Bogousslavsky J, Brass LM, Cimminiello C, Csiba L, Kaste M, Leys D, Matias-Guiu J, Rupprecht HJ ; MATCH investigators: Aspirin and clopidogrel compared with clopidogrel alone after recent ischaemic stroke or transient ischaemic attack in high-risk patients (MATCH) : Randomised, double-blind, placebo-controlled trial. Lancet $364: 331-337,2004$.

10) Diener HC, Connolly SJ, Ezekowitz MD, Wallentin L, Reilly PA, Yang S, Xavier D, Di Pasquale G, Yusuf S; RELY study group: Dabigatran compared with warfarin in patients with atrial fibrillation and previous transient ischaemic attack or stroke: a subgroup analysis of the RE-LY trial. Lancet Neurol 9: 1157-1163, 2010.

11) ESPRIT Study Group: Aspirin plus dipyridamole versus aspirin alone after cerebral ischaemia of arterial origin (ESPRIT) : Randomised controlled trial. Lancet 367: 1665-1673, 2006.

12) European Heart Rhythm Association; European Association for Cardio-Thoracic Surgery, Camm AJ, Kirchhof P, Lip GY, Schotten U, Savelieva I, Ernst S, Van Gelder IC, Al-Attar N, Hindricks G, Prendergast B, Heidbuchel H, Alfieri O, Angelini A, Atar D, Colonna P, De Caterina R, De Sutter J, Goette A, Gorenek B, Heldal M, Hohloser SH, Kolh P, Le Heuzey JY, Ponikowski P, Rutten FH: Guidelines for the management of atrial fibrillation: the task force for the management of atrial fibrillation of the European Society of Cardiology (ESC). Eur Heart J 31: 2369-2429, 2010.

13) Gage BF, Waterman AD, Shannon $W$, Boechler M, Rich MW, Radford MJ : Validation of clinical classification schemes for predicting stroke: results from the national registry of atrial fibrillation. JAMA $285: 2864-2870$, 2001.

14) Gotoh F, Tohgi H, Terashi A, Fukuuchi Y, Otomo E, Shinohara Y, Itoh E, Matsuda T, Sawada T, Yamaguchi T, Nishimaru K, Ohashi Y: Cilostazol stroke prevention study: A placebo-controlled double-blind trial for secondary prevention of cerebral infarction. $J$ Stroke Cerebrovasc Dis 9: 147-157, 2000.

15) Granger $\mathrm{CB}$, Alexander JH, McMurray JJ, Lopes RD, Hylek EM, Hanna M, Al-Khalidi HR, Ansell J, Atar D, 
Avezum A, Bahit MC, Diaz R, Easton JD, Ezekowitz JA, Flaker G, Garcia D, Geraldes M, Gersh BJ, Golitsyn S, Goto S, Hermosillo AG, Hohnloser SH, Horowitz J, Mohan P, Jansky P, Lewis BS, Lopez-Sendon JL, Pais P, Parkhomenko A, Verheugt FW, Zhu J, Wallentin L; ARISTOTLE Committees and Investigators: Apixaban versus warfarin in patients with atrial fibrillation. $N$ Engl $\mathrm{J} \mathrm{Med}$ 365: 981-992, 2011.

16) Hart RG, Pearce LA, Aguilar MI: Meta-analysis: antithrombotic therapy to prevent stroke in patients who have nonvalvular atrial fibrillation. Ann Intern Med 146:857867, 2007.

17) Hirsh J, Bhatt DL: Comparative benefits of clopidogrel and aspirin in high-risk patient populations: lessons from the CAPRIE and CURE studies. Arch Intern Med 164: 2106-2110, 2004.

18) Huang Y, Cheng Y, Wu J, Li Y, Xu E, Hong Z, Li Z, Zhang W, Ding M, Gao X, Fan D, Zeng J, Wong K, Lu C, Ziao J, Yao C ; Cilostazol versus Aspirin for Secondary Ischaemic Stroke Prevention cooperation investigators: Cilostazol as an alternative to aspirin after ischaemic stroke: A randomized, double-blind, pilot study. Lancet Neurol 7:494499, 2008.

19) International Stroke Trial Collaborative Group: The International Stroke Trial (IST) : A randomized trial of aspirin, subcutaneous heparin, both, or neither among 19435 patients with acute ischemic stroke. Lancet $349: 1569$ 1581, 1997.

20) Kennedy J, Hill MD, Ryckborst KJ, Eliasziw M, Demchuk AM, Buchan AM; FASTER Investigators: Fast assessment of stroke and transient ischaemic attack to prevent early recurrence (FASTER) : a randomised controlled pilot trial. Lancet Neurol $\quad 6: 961-969,2007$.

21) Kwon SU, Cho YJ, Koo JS, Bae HJ, Lee YS, Hong KS, Lee JH, Kim JS: Cilostazol prevents the progression of the symptomatic intracranial arterial stenosis: The multicenter double-blind placebo-controlled trial of cilostazol in symptomatic intracranial arterial stenosis. Stroke $\mathbf{3 6}$ : 782-786, 2005.

22) Markus HS, Droste DW, Kaps M, Larrue V, Lees KR, Siebler M, Ringelstein EB: Dual antiplatelet therapy with clopidogrel and aspirin in symptomatic carotid stenosis evaluated using doppler embolic signal detection: the Clopidogrel and Aspirin for Reduction of Emboli in Symptomatic Carotid Stenosis (CARESS) trial. Circulation 111: 2233-2240, 2005.

23) 日本循環器学会, 日本心臓病学会, 日本心電学会, 日本 不整脈学会：心房細動治療（薬物）ガイドライン $(2008$ 年改訂版), 循環器病の診断と治療に関するガイドライン (2006-2007 年度合同研究班報告)。Circ J 72（suppl IV) : 1581-1638, 2008.

24）脳卒中合同ガイドライン委員会（篠原幸人，小川彰，鈴 木則宏, 片山泰朗, 木村彰男) 編 : 脳卒中ガイドライン 2009. 東京, 協和企画, 2009 .
25) Patel MR, Mahaffey KW, Garg J, Pan G, Singer DE, Hacke W, Breithardt G, Halperin JL, Hankey GJ, Piccini JP, Becker RC, Nessel CC, Paolini JF, Berkowitz SD, Fox KA, Califf RM; ROCKET AF Investigators: Rivaroxaban versus warfarin in nonvalvular atrial fibrillation. $N$ Engl J Med 365: 883-891, 2011.

26) Sacco RL, Diener HC, Yusuf S, Cotton D, Ounpuu S, Lawton WA, Palesch Y, Martin RH, Albers GW, Bath P, Bornstein N, Chan BP, Chen ST, Cunha L, Dahlöf B, De Keyser J, Donnan GA, Estol C, Gorelick P, Gu V, Hermansson K, Hilbrich L, Kaste M, Lu C, Machnig T, Pais P, Roberts $\mathrm{R}$, Skvortsova V, Teal P, Toni D, Vandermaelen C, Voigt T, Weber M, Yoon BW ; PRoFESS Study Group: Aspirin and extended-release dipyridamole versus clopidogrel for recurrent stroke. N Engl J Med 359: 1238-1251, 2008.

27) Shinohara Y, Katayama Y, Uchiyama S, Yamaguchi $T$, Handa S, Matsuoka K, Ohashi Y, Tanahashi N, Yamamoto H, Genka C, Kitagawa Y, Kusuoka H, Nishimaru K, Tsushima M, Koretsune Y, Sawada T, Hamada C ; CSPS 2 group: Cilostazol for prevention of secondary stroke (CSPS 2) : an aspirin-controlled, double-blind, randomised non-inferiority trial. Lancet Neurol 9:959-968, 2010 .

28) Toyoda K, Yasaka M, Iwade K, Nagata K, Koretsune Y, Sakamoto T, Uchiyama S, Gotoh J, Nagao T, Yamamoto M, Takahashi JC, Minematsu K; Bleeding with Antithrombotic Therapy (BAT) Study Group: Dual antithrombotic therapy increases severe bleeding events in patients with stroke and cardiovascular disease : a prospective, multicenter, observational study. Stroke 39: 1740-1745, 2008.

29) Toyoda K, Yasaka M, Uchiyama S, Nagao T, Gotoh J, Nagata K, Koretsune Y, Sakamoto T, Iwade K, Yamamoto M, Takahashi JC, Minematsu K ; Bleeding with Antithrombotic Therapy (BAT) Study Group : Blood pressure levels and bleeding events during antithrombotic therapy: the Bleeding with Antithrombotic Therapy (BAT) study. Stroke 41: 1440-1444, 2010.

30) Uchiyama S: Results of the Cilostazol Stroke Prevention Study II (CSPS II ), a randomized controlled trial for the comparison of cilostazol and aspirin in stroke patient. RinshoShinkeigaku 50:832-834, 2010.

31) Wong KS, Chen C, Fu J, Chang HM, Suwanwela NC, Huang YN, Han Z, Tan KS, Ratanakorn D, Chollate P, Zhao Y, Koh A, Hao Q, Markus HS ; CLAIR study investigators: Clopidogrel plus aspirin versus aspirin alone for reducing embolisation in patients with acute symptomatic cerebral or carotid artery stenosis (CLAIR study) : a randomised, open-label, blinded-endpoint trial. Lancet Neurol 9: 451-453, 2010.

32) Yasaka M, Sakata T Minematsu K, Naritomi H: Correction of INR by prothrombin complex concentrate and vitamin $\mathrm{K}$ in patients with warfarin related hemorrhagic complication. Thromb Res 108:25-30, 2002. 
旨

抗血小板療法と抗凝固療法

宮下 史生 豊田 一則

アスピリンは, 脳梗塞患者の急性期抗血栓療法と再発予防目的で強く勧められている. クロピドグ レルやシロスタゾールは, 脳梗塞再発予防目的でアスピリンと同等以上の効果を示す，一般的な脳梗 塞再発予防に，抗血小板薬の併用療法は出血の危険性から勧められていない. 抗凝固療法については, non valvular atrial fibrillation（NVAF）患者の脳梗塞予防において，ワルファリンに加えてダビガトラ ンが認可され，その他の新規薬剤も臨床試験中である，抗凝固療法を行う際には，CHADS 2 スコアや $\mathrm{CHA}_{2} \mathrm{DS}_{2}$-VASc スコア, HAS-BLED スコアで塞栓症と出血の危険性を評価していくことが望まれる. BAT 研究において，日本人における抗血栓療法施行中の出血について報告されている. 